Intervenção do Professor Leodegário A. de Azevedo Filho, consultando - Presidente sobre a possibilidade de tempo para discussão de assuntos gerais.

Devido ao adiantado da hora, o Presidente consultou o Coordenador Geral, Professor Dr. David Antônio da Silva Carneiro, a respeito da sessão de encerramento.

Intervenção do Professor Artur Anselmo, sollcitando a indicação do grupo de trabalho sugerido em sua proposta (número 4) e já aprovada por unanimidade.

O Presidente encaminhou ao Professor Carlos D'Alge, da Universidado Federal do Ceará, a identificação dos elementos que constituirāo o referido grupo, por ocasiāo do vindouro Encontro, em 1977.

A 6.' proposta, do Professor Ildásio Tavares, da Universidade Federal da Bahia, tratou do temário do próximo Encontro, que deve versar sobre problemas inerentes ao ensino da Literatura Portuguesa no Brasil, visando a aperfeiçoátlo e melhorállo em sentido prático de sua problemática no nosso Pais.

Intervençāo do Professor Leodegário A. de Azevedo Filho, sugerindo que as comunicaçōes apresentadas nos futuros Encontros acrescentem algo de original, nāo permanecendo nas citaçōes já conhecidas, cansativas pela redundância.

O Presidente, Professor Naief Safady, da UFMG, agradeceu a atençāo de todos, e considerou encerrada a sessão, que secretariel, e da qual fiz o presente relatório.

Curitiba, 27 de outubro de 1976.

(A.) Maria Carolina Brasileiro de Castro, da Faculdade de Filosofia, Ciênclas e Letras de Lavras, Minas Gerais.

\title{
COMUNICAÇÃO PROPOSTA PELO PROF. DR. MASSAUD MOISES
}

(Aprovada por aclamação na sessão de 27-10-1976)

O signatário propōe que o IV Encontro de Professores Brasileiros de Lite- 
ratura Portuguesa, realizado em Curitiba entre 24 e 27 de outubro de 1976. se dirlja ao MEC, e às Secretarias de Educação dos Estados no sentido de que sejam tomadas providências a fim de se fazer cumprir o Parecer n. $853 / 71$ (aprovado em 12-11-1971 e homologado pelo Senhor Ministro da Educação e Cultura), que discute a doutrina do Curriculo, e no item que trata dos Objetivos, reza: "As situaçōes criadas a os textos escolhidos para leitura, em articulação com as outras matérias, devem conduzir a uma compreensão e apreciaçāo da nossa História, da nossa Literatura, da Civilizaçāo que vimos construindo e dos nossos valores mais típicos. Isto, evidentemente, năo há de conduzir a exclusivismos estreitos. Assim como a nossa História Universal, a Llteratura Brasileira não poderá ser estudada com abstração de suas raizes portuguesas e sem inserir-se no complexo cultural europeu de que se origina, (grifo nosso) - numa evidente tentativa de evitar que se extraiam da Lei aquelas falsas deduçōes acima levantadas, isto é, aquelas segundo as quais estaria eliminada do nosso ensino de $10^{\circ}$ e $20^{\circ}$ grau a Literatura Portuguesa".

Em reforço da presente proposta, o signatário deseja lembrar: 1) que o Relatório de um grupo de trabalho convocado pelo Sr. Ministro da Educaçăo para dar sugestões acerca do ensino de Português no $10^{\circ}$ e $20^{\circ}$ graus, preconizou "que o ensino da literatura se faça em função dos textos examinados em classe, sem desestimular a leitura direta de obras dos autores brasileiros e portugueses" e "que os textos das séries do $2 .^{\circ}$ grau ilustrem todas as fases das literaturas brasileira e portuguesa, ressaltando os estilos de época e a evaluçāo dos gêneros literários" (pág. 21); e 2) que a recente Proposição Curricular de Comunicaçăo e Expressão (2. Grau), elaborada por uma equipe de professores de Português em atendimento a solicitação do Secretário de Educação do Estado de São Paulo: a) ao focalizar os dois aspectos, ou seja, "a relação sincrônica e diacrônica dos textos líterários entre si" e "a relação da série literária com as outras séries culturais", também conclui que "esses dois aspectos deverão constituir o objeto do estudo da história das literaturas em língua portuguesa, estudo esse que deverá partir sempre da análise de textos especificos"; e b) ao deter-se no estudo comparativo de textos, sublinha que "deverão ser enfatizadas, com base na análise de dados concretos, as inter-relaçōes existentes entre a literatura brasileira e a portuguesa, e poderāo também constitulr objeto de leitura e análise comparativa textos de outras literaturas de expressão portuguesa" (págs. 10 e 11). 